вздовж один за одного, буде менша довжина рукавів йти на зав'язування, а також буде економія коштів на вартості рукавів, вартості робочого часу та палива (зменшується кількість переїзів спецтехніки). Доцільно враховувати можливість розвантаження рукава впродовж однієї зміни.

На всіх етапах (завантаження, зберігання, вивантаження) щуотижнево визначають якість зерна, спостерігають за станом та відновлюють иілісність рукавів, перевіряють санітарний стан площадки та наявність приманок. Обов'язковим є охоронні заходи, облік зерна, робота з некондиційним зерном та підсумковий аналіз результатів зберігання зерна.

Ключові слова: зернова маса, полімерні зернові рукави, майданчик для зберігання, герметичні умови зберігання, якість зерна.

Надійшла 07.03.2019. Рецензія 29.04.2019.

До друку 07.06.2019.

Адреса для переписки:

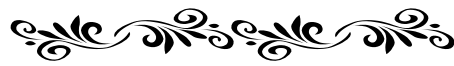

вул. Канатна, 112, м. Одеса, 65039

UDK [577.114.4:633.11]:57.0.13

${ }^{1}$ L.V. KAPRELYANTS, Dr. of tech. science, professor ${ }^{1}$ L.G. POZHITKOVA, PhD of tech. science, assistant, professor

${ }^{1}$ T. A. VELICHKO Dr. of tech. science, professor

${ }^{2}$ O. A. BILYK, PhD of tech. science, associate, professor

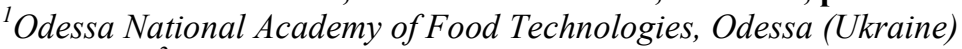

${ }^{2}$ National University of Food Technology, Kyiv (Ukraine)

\title{
WHEAT ARABINOXYLANS: STRUCTURE, EXTRACTION AND CHARACTERISTICS
}

\begin{abstract}
Wheat bran is a by-product of conventional milling and is commercially available in large quantities. Beside its high content of dietary fibre it contains proteins, minerals as well as vitamins and others biologically active components. In recent years, there have been designed different approaches to incorporation of wheat bran in food products to optimize composition or physiological effects. Industrial wheat bran is one of the most representative available hemicellulosic rich products. Arabinoxylans are the predominant non-starch polysaccharides found in the structural matrix of cell walls in wheat grains, being present in large quantities in wheat bran, accounting for up to 15-20\% of its composition.

Their physicochemical properties define their functionality which can be beneficial in cereal-based products such as bread, where their addition could enhance the gluten matrix responsible for the aerated structure and quality of bread. A potential source of arabinoxylans is its extraction from the wheat bran based low value as an end product of the milling process. The benefits of extraction are twofold, to enhance nutritional value wheat by-product reducing fibre content and produce a high value product for use as a functional ingredient in the bread making industry and in others foods. Extraction of arabinoxylans involves many possibilities for obtaining substances with different physicochemical properties, giving opportunity for integration in functional foods. Functional behaviour includes viscosity, water solubility, water holding capacity, oxidative cross linking and gel formation and foam stability, which are all reported to be affected by the physicochemical properties of arabinoxylans, as well as chain to chain interactions with other polymers and with the solvent.

Currently no commercial supply of arabinoxylans is available in sufficient quantities to conduct functionality trials; therefore the objective of the current work was to study the feasibility of extracting arabinoxylans from the bran for future developing and scaled-up extraction process based on the analyzed methods and approaches.

Keywords: arabinoxylans wheat, structure, classification, method of extraction, physicochemical properties, molecular weight, viscosity, water solubility.
\end{abstract}

Wheat is among the oldest grown of all crops. Nowadays, in terms of production, wheat ranks first among all cultivated plants. The estimated production of wheat in 2019 in Ukraine is 75 million tonnes, of which Triticum aestivum is the predominant species. The major use of wheat is for human consumption.

Wheat bran is a by-product of conventional milling and is commercially available in large quantities. Beside its high content of dietary fibre it contains proteins, minerals as well as vitamins and others biologically active components $[1,2]$.

Despite the presence of physiologically relevant nutrients, wheat bran is not a significant component of the human diet, but is mainly used as animal feed; high phytate content, brownish colour and gritty mouth-feel might limit acceptance as food. In recent years, there have been designed different approaches to incorporation of wheat bran in food products to optimize composition or physiological effects. Its use as a source of dietary fibre is indicated by epidemiological and experimental studies, which pointed to possible effects against colon cancer. Moreover, human intervention studies indicated that wheat bran, but not oat or corn bran, significantly decreased the levels of several tumour promoters in the colon [3].

Industrial wheat bran is one of the most representative available hemicellulosic rich products. The main hemicellulosic component is the arabinoxylans, 
which consists of two pentose sugars: arabinose and xylose.

Anatomically, the aleurone layer constitutes the outer layer of the endosperm. However, due to its high adherence to the pericarp, it is found predominantly in the bran fractions after milling. In wheat, aleurone consists of a mono-layer of cubic cells with cell walls being $6-8 \mathrm{~mm}$ thick. The cell walls consist mainly of polysaccharides, arabinoxylans (AXs) being the predominant fraction. AXs represent a considerable part of the building blocks of cell walls in cereals. These nonstarch polysaccharides are of growing importance in human diets with health promoting characteristics and are a major determinant in the performance of cereals in biotechnological processes [3, 4].

AXs are valuable compounds and wheat bran may be a source of choice since it is a highly available and cheap agriculture by-product. The commercial value of AXs stems mainly from their applications as food ingredients, but various other prospects have been arising in many industrial sectors, such as cosmetics, pharmaceutics, traditional or green chemistry, etc [5].

Recent research has focused on the bioactivities and health benefits of cereal AXs. Based on the scientific data obtained in intervention studies, the European Food Safety Authority (EFSA) has approved that the health benefit of the reduction of post-prandial glycaemic response can be claimed on foods containing more than 4,8 g. of wheat endosperm AXs per $100 \mathrm{~g}$ available carbohydrates [6].

AXs can be used as a source of fiber, providing the known associated health benefits. Moreover, the prebiotic character of arabinoxylooligosaccharides (AXOS) has attracted a great deal of interest in the field of nutrition, both in scientific research and in food applications, or as feed additives $[7,8]$.

A prebiotic is a non-digestible and selectively fermented food ingredient that allows specific changes, both in the composition and/or activity in the gastrointestinal microflora that beneficially affects the host $[9,10]$.

A second potential health benefit may result from the phenolic acids associated to AXs, and which are known to exhibit very strong antioxidant, free radical scavenging and anti-inflammatory activities. Ferulic acid associated with AXs (linked or not) was demonstrated to have strong antioxidant activities (mainly when not bonded) [11].

Moreover feruloylated AXs decreased the oxidation of human low density lipoprotein, i.e. a potential role in preventing or reducing the progression of atherosclerosis, AXs exhibit functional properties related to their molecular mass, which may affect the structure, the texture or the appearance of food products $[12,13]$.

Thus, the incorporation of bioactive AXs into foods becomes an alternative method to enhance the nutritional values of foods. The aims of this review are to analyze existing methods of isolation AXs from wheat bran, their functional properties and the health benefits and to examine the changes in the extractability and molecular features of AXs [12].

AXs are branched polysaccharides found in the outer layers and endosperm of cereal cell walls. They were first isolated in wheat flour in 1927 by Hoffman, being referred to as pentosanes, and since then have been found in cereal grains such as barley, oats, rye, rice sorghum, corn, maize and millet and plants such as bamboo, rye grass, flaxseeds and banana peel. They are of interest due to their functional properties, and have potential to be exploited for both food and non-food uses [14, 15].

To understand the occurrence of AXs in wheat, the structure of the wheat grain must be examined. Complex architecture of the wheat kernel, which is made up of many different tissues, each having cell walls of different compositions and properties, within which AXs, along with other constituents. A wheat grain is on average between 4 to $10 \mathrm{~mm}$ in length, with a width and depth from 2,5 to $4,5 \mathrm{~mm}$, being widest around the middle of its large axis, and weighs about $35 \mathrm{mg}$, these factors vary depending on the location of the grain in the growing spike, the wheat cultivar and the growing environment. Each grain is a seed, and in the right conditions is viable to germinate and grow into a new plant $[16,17]$.

It is important to note that bran is not a botanical term; it is a term referred to by millers, being made up of two principal components, the pericarp and aleurone layers. Botanically, the aleurone is part of the endosperm; but it is generally removed during the milling process along with the pericarp, nucellar tissue and seed coat to form bran. The percentage of bran in comparison to endosperm and the germ is shown in table $1[10,18,19]$.

Table 1 - The \% of bran, endosperm and germ from a wheat grain of Ukraine

\begin{tabular}{|c|c|c|c|c|}
\hline \multirow{2}{*}{ Grain constituent } & \multicolumn{4}{|c|}{$\%$ of grain* } \\
\hline & 1 & 2 & 3 & 4 \\
\hline Endosperm & 82,9 & 80,7 & 81,6 & 81,7 \\
\hline Bran & 14,6 & 16,4 & 15,0 & 15,3 \\
\hline Germ & 2,5 & 2,9 & 3,4 & 2,9 \\
\hline
\end{tabular}

* Winter wheat varieties: 1- Bezostaya 1; 2- Odeska 162; 3 -Albatros Od; 4 - average value;

A grain is predominantly made up of starchy endosperm $(\sim 69 \%)$, with non-starch polysaccharide and protein both representing around $11 \%$ of the total composition, sugars and oil $3 \%$ each, ash $2 \%$ and lignin $1 \%$. When wheat is milled, the purpose is to separate the starchy endosperm from the outer bran layers of the grain in differing proportions and fractions for use in various commercial processes, with the bran a by-product that generally goes to animal feed.

Commercial wheat bran is made up of the outer layers of the grain (pericarp, testa and nucellar layers), the aleurone layer and remnants of starchy endosperm, and typically contains 38\% glucuronoarabinoxylan, 16\% cellulose, $6,6 \%$ lignin, $25 \%$ protein and some $(1,3)(1,4)-$ $\beta$-D-glucans. Presence of AXs and $\beta$ - glucan in the aleurone cell walls of the wheat grain, which forms part of commercial wheat bran. To perform the function of protecting the kernel, cell walls in bran tissues are thick, hydrophobic and formed primarily of cellulose, complex xylans and lignin $[20,21]$.

These cell walls are therefore a good source of AXs, which is found as part of the complex xylans in the cell walls of each of these tissues in differing propor- 
tions. In contrast, cell walls in endosperm are thin, hydrophilic and formed mainly of two polymers: AXs and $(1,3)(1,4)-\beta$-D-glucans, with small amounts of glucomannan, cellulose, structural protein and arabinogalactan peptides $[21,22]$. This is because the components of the cell walls have different functions within the grain, and it is reasonable to hypothesise that extracted AXs would have different functional properties as a result. Although AXs are a minor constituent of the entire grain, around $6-8 \%$, they are the major hemicellulose component in the non - starch polysaccharide (NSP) content of the cell wall in all the grain's tissues $[23,24]$. NSP represents $2-2,5 \%$ of endosperm, and $46 \%$ of wheat bran content, being made up of $70 \% \mathrm{AXs}$, $24 \%$ cellulose and $6 \% \beta$-glucans, with minute amounts of glucomannan and arabinogalactan from aleurone and endosperm cells also present. [16, 23, 25] The amounts of AXs found in wheat bran have been reported by several workers, as summarised in table 2, ranging between 11 and $25 \%$ of bran, in contrast to $1-3 \%$ AXs found in endosperm.

Although whole bran is a good source of AXs, its content within the tissue components of the different bran layers in the grain varies. Pericarp and test a contain the highest levels of AXs ( $\sim 64-70 \%$ of the cell wall), while aleurone contains lower levels of $1,8-4 \%[15,26-$ 28].

Table 2 - Amount of arabinoxylans in wheat bran and endosperm

\begin{tabular}{|c|c|c|}
\hline Source & $\begin{array}{c}\text { Total Arabinoxylans } \\
(\%)\end{array}$ & Author \\
\hline Whole Grain & $6-8$ & [3] \\
\hline Bran & 17,7 & [12] \\
\hline Bran & 19 & {$[26]$} \\
\hline Bran & 19,38 & {$[13]$} \\
\hline Bran & $20-25$ & {$[15,20]$} \\
\hline Bran & 25 & {$[29]$} \\
\hline Coarse Bran & $11,5-22,5$ & [30] \\
\hline Endosperm & $1,37-2,06$ & {$\left[\begin{array}{l}13,23] \\
\end{array}\right.$} \\
\hline Endosperm & $2-3$ & [31] \\
\hline & & \\
\hline
\end{tabular}

(a)

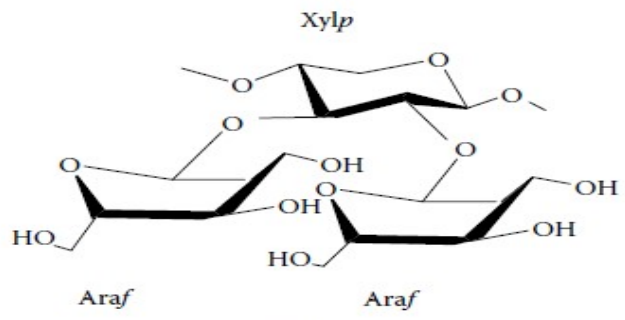

(c)
Fractions containing 4\% pearlings had the highest AXs content for all cultivars, ranging from $20-35 \%$ dry matter $(\mathrm{dm})$ of the fraction, in comparison to $12 \%$ pearlings with $7-12 \%(\mathrm{dm})$, whole bran which contained $11,5-22,5 \%(\mathrm{dm})$ and whole grain which contained $4,5-9 \%(\mathrm{dm})$. This work reflects that $4 \%$ pearlings contain mainly pericarp, which has the highest level of AXs, whereas $12 \%$ pearlings are more likely to contain aleurone and some starchy endosperm with reduced levels of AXs.

\section{Structure of AXs}

All AXs in wheat grain have a general structure formed from the monomers $\alpha$-L-arabinose and $\beta$-Dxylose, conformed as linear (1-4)- $\beta$-D-xylopyranosyl (xyl $p$ ) chains with $\alpha$-L-arabinofuranosyl (araf) residues attached as side branches. Three dimensionally, their structure is a random coil conformation that exhibits varying degrees of flexibility [23].

This is due to the botanical source, and the heterogeneity displayed in the degree of substitution, substitution pattern, molecular weight and coupling of ferulic acid to other AXs molecules or the cell wall by AXs from different tissues in the grain $[27,33]$.

The arabinose to xylose ratio is often used to characterise the structure of AXs, however this ratio only reflects the amount of arabinose to xylose on the chain and does not describe the substitution pattern, which better describes their structure. Together these features affect the capacity of AXs to interact with each other and/or with other polysaccharides, and determine the physical and functional properties of the macromolecules $[16,21,24]$

Four basic building blocks can be seen in the molecular structure of AXs, as shown in figure 1, and it is the configuration of these that make up the molecule's substitution pattern. Arabinose residues can be linked along the xylan backbone at the $\mathrm{C}(\mathrm{O})-2$ or $\mathrm{C}(\mathrm{O})-3$ positions $(\mathrm{a}, \mathrm{b})$ or both $\mathrm{C}(\mathrm{O})-2$ and $\mathrm{C}(\mathrm{O})-3$ positions $(\mathrm{c})$, or the xylose can be unsubstituted (d).

Although based on the same basic structure, a clear difference is evident in the structure between AXs found in wheat bran and endosperm.

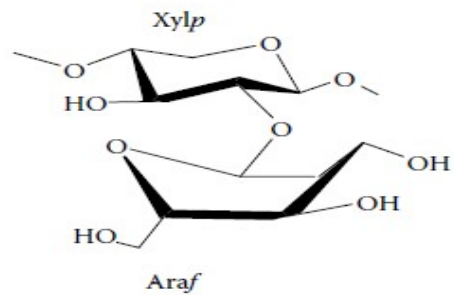

(b)

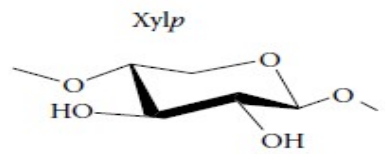

Fig. 1 - The four main building blocks in the molecular structure of AXs [13] 


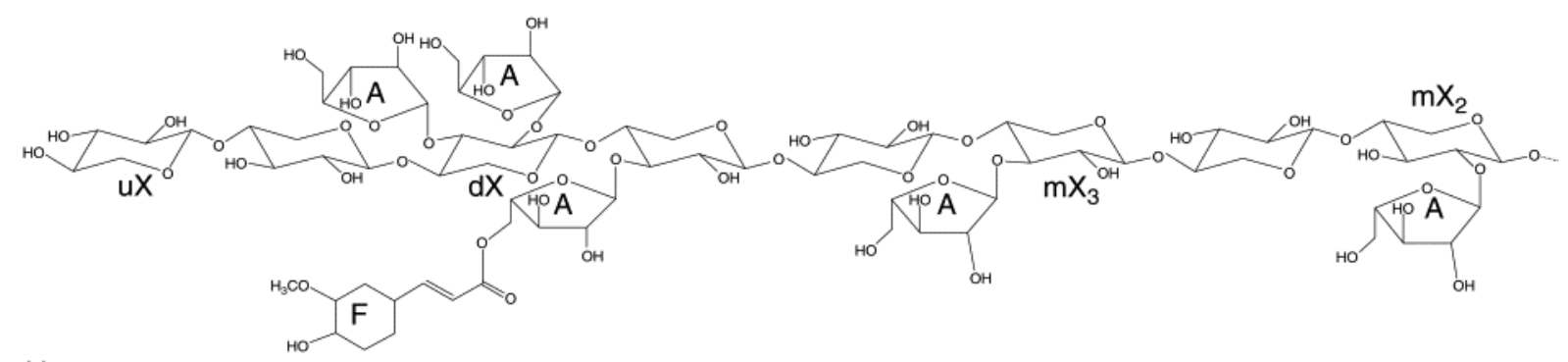

(a)

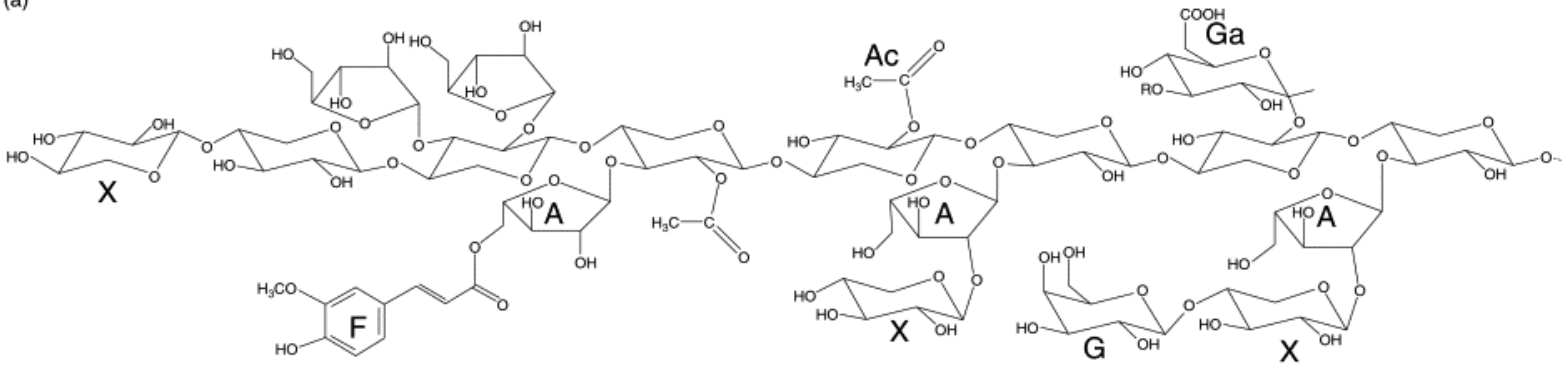

(b)

Fig. 2 - Main structural features of AXs from Endosperm (a) and outer tissues (b) of cereal grains A: arabinose; X: xylose; G: galactose; Ga: glucuronic acid; F: ferulic acid; $u X$ : unsubstituted xylose; dX: di-substituted xylose; mX3: O-3 mono-substituted xylose; $m X 2:$ O-2 mono-substituted xylose (rare in wheat endosperm AXs) [21]

\section{Structure of wheat bran AXs}

The main structural differences between wheat bran AXs and endosperm are shown in figure 2. As with endosperm AXs, wheat bran AXs display arabinose residues linked at the $\mathrm{C}(\mathrm{O})-2, \mathrm{C}(\mathrm{O})-3$ or both $\mathrm{C}(\mathrm{O})-2$ and $\mathrm{C}(\mathrm{O})-3$ positions to the xylose backbone, along with the presence of ferulic acid at $\mathrm{C}(\mathrm{O})-5$. The difference is the presence of uronic acid, mainly glucuronic acid at the $\mathrm{C}(\mathrm{O})-2$ position and ferulic and p-coumaric acids esterified to some of the arabinose residues, along with short side chains of $\alpha-(1-2)$ - and $\alpha-(1-3)-$ linked arabinose. As a result, these molecules are sometimes referred to as glucuronoarabinoxylan's $[15,20]$.

The many tissues making up wheat bran have different AXs structures, and depending on the origin of $\mathrm{AXs}$, the degree of substitution $(\mathrm{A} / \mathrm{X}$ ratio) can vary from 0,2 to 1,4 due to the proportion of open and branched regions on the polymer chain $[15,16]$. AXs from the aleurone layer and the intermediate layers (comprising nuclear epidermis and seed coat) are characterized by low $\mathrm{A} / \mathrm{X}$ ratios $(0,3-0,5$ and 0,1 respectively), while the $\mathrm{A} / \mathrm{X}$ ratio of outer pericarp (epidermis and hypodermis) is much higher at $1,1[21,26]$.

Monomeric ferulic acid is present in higher levels in the AXs found in aleurone than in the outer pericarp. Cross linking between AXs chains can occur through the formation of diferulate bridges. The average number of xylose units between diferulate bridges is represented by the molar ratio of xylose to ferulic acid molecules and indicates the level of cross linking. Using this ratio, AXs of the aleurone layer and pericarp are 2 and 6 times more cross linked than the intermediate layers, respectively [26].

$\mathrm{A} / \mathrm{X}$ ratios of overall wheat bran AXs populations range from 0,54 to 0,71 and water - extractable AXs (WEAX) and alkali-extractable AXs (AEAX) with A/X ratios of 0,45 and 0,82 respectively, have been isolated from wheat bran. Ferulic acid and diferulic acid levels are 4,3-6,6 $\mathrm{g} / \mathrm{mg}$ and $0,3-0,8 \mu \mathrm{g} / \mathrm{mg}$, respectively. An average molecular weight (MW) of $293 \mathrm{kDa}$ has been determined for wheat bran AEAX, although WEAX and AEAX molecular weights between 50 to above $2000 \mathrm{kDa}$ have been isolated $[15,16]$.

\section{Enzyme technology treatment of wheat bran AXs}

Many of the wheat bran bioactives occur bound to fiber or protein, and trapped in the aleurone cells. This is the case of the phenolic acids that are covalently bound to cell-wall polysaccharides, mainly to AXs. The backbone of AXs is composed of b-(1,4)-linked xylose residues, which can be bound to arabinose residues on the $\mathrm{C}(\mathrm{O})-2$ and/or $\mathrm{C}(\mathrm{O})-3$ position. Ferulic acid can be esterified on the $\mathrm{C}(\mathrm{O})-5$ position of arabinose in figure 3 . Most of the ferulic acid in wheat bran is bound to AX, which limits its bioaccessibility and bioavailability from bran rich products [34-36].

There are numerous enzymes targeting specific linkages of the AXs structure. Endo-b- $(1,4)$-D-xylanases cleave the xylan backbone internally, b-D-xylosidases remove xylose monomers from the non-reducing end of xylooligosaccharides, $\alpha$-L-arabinofuranosidases remove arabinose substituents from the xylan backbone, and ferulic acid esterase's remove ferulic acid groups from arabinose substituents [37, 38]. Therefore strategies that involve the use of these and other enzymes are likely to cause a food matrix restructure that facilitates the release of the embedded compounds, such as ferulic acid. Furthermore, a synergy in the enzymatic release of ferulic acid from wheat bran has been reported for ferulic acid esterase and xylanases, which makes the combination of these enzymes an interesting approach to improve the ferulic acid bioaccessibility. It has been observed that treatment of wheat bran insoluble dietary fibre with xylanases released feruloylated oligosaccharides from the bran and feruloyl oligosaccharides have been reported to protect against oxidative DNA damage in normal human peripheral blood lymphocytes [39].

Treatment of wheat fiber with the hydrolytic enzymes (mainly 1,3-b-glucanase and xylanase activities) of Tricoderma produced an increase in the soluble fiber 
as well as a four times increase of the water extractable ferulic acid. In another study with wheat grain treated with the fungi Aspergillus, a positive correlation was found between the phenolic content of the wheat extracts and the activities of the hydrolyzing enzymes $\alpha$-amylase, b-glucosidase and xylanase [40].

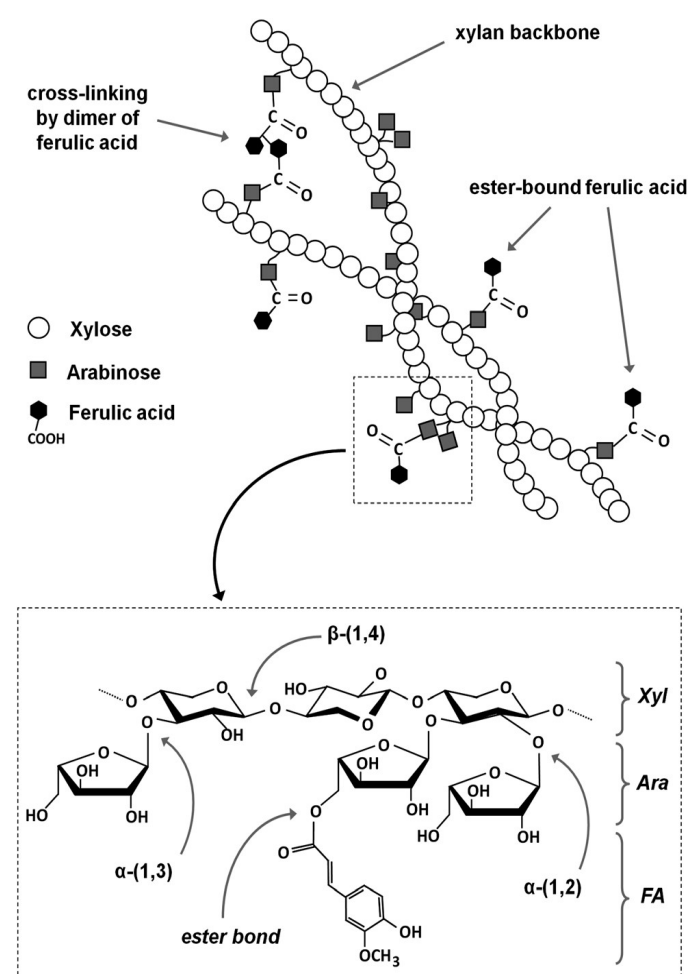

Fig. 3 - Ferulic acid bound to the AXs structure in wheat bran

Moore et al. tested five commercial foods - grade enzyme preparations with reported enzyme activities, such as b-glucanase, cellulose, polygalacturonase, aminopeptidase, and other side activities, on wheat bran. The most efficient enzyme preparation (mainly bglucanase activity) released $50 \%$ of the insoluble bound ferulic acid to its soluble free form, which is the bioaccessible form. Other bound phenolic acids were also released by the enzyme treatment, such as p-coumaric acid, syringic acid and vanillic acid. The increase in free phenolic acids was in line with an increase in the antioxidant capacity, measured by different assays: hydroxyl radical scavenging, DPPH scavenging, ABTS scavenging and oxygen radical absorbing capacity [41].

In a study by the authors, wheat bran was treated with an enzyme mixture, consisting of xylanase, bglucanase, cellulose, $\alpha$-amylase and ferulic acid esterase, before adding it to wholemeal flour for bread making. The main enzyme activities of this treatment were xylanase and b-glucanase activities. The enzyme treatment was applied on yeast fermented bran to enrich wholemeal bread. The bioaccessibility of phenolic acids from wholemeal bread with enzyme treated and fermented bran was compared to that with just fermented bran in the TNO Intestinal Model (TIM) of the gastrointestinal tract. The bioaccessibity of ferulic acid, p-coumaric acid, and sinapic acid from the wholemeal bread with enzyme treated and fermented bran was higher than that of the wholemeal bread with fermented bran. The highest in- crease was in the bioaccessibility of ferulic acid, which was 2,5-fold that of the wholemeal bread with just fermented bran. Despite this increase, the bioaccessibility of ferulic acid was merely 5,5\%, meaning that even with the enzyme treatment most of the ferulic acid in wheat bran is not released in the small intestine. Most of it remains bound to the cell walls that constitute the indigestible fraction that enters the large intestine.

Further, colonic experiments by the authors revealed that ferulic acid is mostly bioconverted by the colonic microbiota into other compounds of different chemical structure and bioactivities, mainly phenylpropionic acids with different grades of hydroxylation. These colonic metabolites of ferulic acid were found at higher concentrations when the bran was treated by fermentation and hydrolytic enzymes [42].

The in vitro results obtained with the intestinal models described above have been confirmed in vivo by a follow-up study in humans by the authors. The human trial was a cross-over postprandial study, in which the participants had to consume $300 \mathrm{~g}$ of wholegrain bread with wheat bran or wholegrain bread with bioprocessed wheat bran. The bioprocessing of the bran was a combined treatment of yeast fermentation and hydrolytic enzymes, the same as in the in vitro studies described above. The wheat bran bioprocessing increased the bioavailability of ferulic acid and other phenolic compounds by a factor of 2,5 from the bread. This could be further associated with an increase in the anti-inflammatory capacity in an ex vivo LPS - induced inflammatory response [43].

\section{Classification of AXs according to extractability}

Not all AXs present in the cell walls are immediately extractable in aqueous solution. The substitution pattern and resultant helix formation and flexibility determine the WEAX. AXs therefore become classified according to their extraction methods into WEAX and water-unextractable (WUAX), with different functional properties being displayed by the AXs obtained from the different extraction techniques [44, 45].

Extractability of AXs is affected by several factors. Due to large MW and high ferulic acid content, AXs molecules are physically and chemically associated with each other through cross linking and readily form a network matrix of covalent (e.g. ester and ether bonds and diferulic acid bridges) and non - covalent (e.g. hydrogen bonds) linkages with other cell wall components such as proteins, $\beta$-glucans, lignin and cellulose. This cross linking happens due to the presence of phenolic compounds such as ferulic acid (FA) which can undergo coupling reactions to produce diferulic acid (DFA) $[13,16$, 33].

It is the formation of the arabinose - DFA cross - links which forms the rigid network between AXs and other cell wall materials. WUAX are retained in the cell wall by non - covalent (e.g. hydrogen bonds) and covalent interactions (e.g. ester and ether bonds, diferulic acid bridges) with other AXs molecules or with other cell wall constituents. As a result of these linkages, a large proportion of AXs cannot be extracted by water as it is retained in the cell wall. WUAX must be treated in some way to break the bonds between the AXs molecules and other 
constituents. This liberates the AXs, making it water soluble $[15,23]$.

By contrast, WEAX is thought to be loosely bound to the cell wall surface and easily solubilised in water and therefore extracted. Suggestions for this phenomenon include incomplete cross - linking, small structural differences or initial enzymatic degradation in the kernel. The literature also confirms that the solubility of AXs is primarily dependent on the degree of substitution, with less substituted AXs having lower solubility in water $[15,20]$.

\section{Methods of AXs extraction}

Although the easiest method of extraction is with water, the amount of WEAX is much lower that the levels of WUAX found in the cereal grain. In a quest to increase AXs extraction yields through extraction of WUAX, much research has been conducted to improve solubility of the WUAX fraction. Different methods have been developed and reported for the extraction and purification of WUAX, with varying extraction yields and macromolecular characteristics being observed [15].

These include alkaline and acid extraction, enzyme hydrolysis, and mechanical - chemical extraction in the forms of: microwave - assisted extraction, ultrasound - assisted extraction, steam explosion extraction and hot compressed water extraction. The literature relating to water, alkaline and enzyme extraction methods is introduced below, with other mechanical - chemical extraction methods outside the scope of the current work [20, 29, 30].

Enzymatic degradation can also be used as a method for isolating AXs from wheat bran and is also commonly used in the production of AXs oligosaccharides (AXOS). The most commonly used enzymes are GH 11 endo- $\beta-(1,4)$-xylanases. These enzymes attack the xylan backbone, cleaving $\beta$ - $(1,4)$-linkages along the chain in a random manner, penetrating the cell wall network and depolymerizing WEAX to produce mixtures of (un)substituted xylooligosaccharides as well as solubilizing and extracting some WUAX. Zhou report that the use of endoxylanases on destarched wheat bran resulted in lower AXs yields compared to those using alkaline hydrogen peroxide, being $12,4 \%$ and $18,55 \%$, respectively. It is thought that the presence of enzyme inhibitors and the crystalline structure of lignocellulose could limit enzyme hydrolysis [16, 17, 25].

Enzyme hydrolysis can also be used as a technique to modify the structure of AXs. AXs have been produced by a range of workers with different substitution patterns, degrees of branching, $\mathrm{A} / \mathrm{X}$ ratios and $\mathrm{MW}$, by using enzymes to break down the polysaccharide, releasing up to $50 \%$ of the ferulic acid and removing up to $30 \%$ of the arabinose side chains $[15,17]$.

When comparing extraction of AXs with alkaline hydrolysis to extraction with endoxylanases, a reduction in the MW distribution is seen. Average MW of AXs from alkaline extraction of 3,5 x 105 Da about 10 times that of AXs extracted from enzymes which produced an average MW of 3,252 x $104 \mathrm{Da}$. It is thought that this is as a result of endoxylanases working on the $(1,4)-\beta$-links on the xylan backbone, in contrast to alkaline hydrolysis which breaks down diferulate bridges and hydrogen bonds attaching lignin and cellulose to AXs [25].

\section{functionality}

MW, degree of substitution (DS) arabinose/xylose ratio (A/X ratio), substitution pattern, degree of polymerisation (DP), presence of other substituents such as feruloyl groups and the extent of cross linking are all important in defining the behaviour and functionality of AXs. Functional behaviour includes viscosity, water solubility, water holding capacity, oxidative cross linking and gel formation and foam stability, which are all reported to be affected by the physicochemical properties of AXs, as well as chain to chain interactions with other polymers and with the solvent [32].

\section{Molecular Weight}

MW is a key factor in determining the physicochemical properties of AXs, in particular viscosity, and is dependent on the origin of AXs in the wheat grain tissue and cultivar. Molecular weights for AXs reported in literature vary depending on the isolation method used and source of the AXs [13].

Determining the MW of WUAX is reported to be problematic, as the method of extraction can lead to degradation of the polymer chain, and thus changes in MW. Also AXs from the outer part of the grain tends to form aggregates which make it almost impossible to determine the MW of individual chains in aqueous systems [16].

Using graded ethanol precipitation, MW for WEAX from wheat bran is reported to be lower than that of AEAX ranging from $<5-50 \mathrm{kDa}$ and $<5-293 \mathrm{kDa}$ respectively, with a high degree of substitution. In general, the MW for WEAX and AEAX from wheat endosperm AXs are higher than that found in wheat bran; however as with the AXs in bran, MW from endosperm WEAX is also lower than that from endosperm AEAX $[15,23]$.

MW for wheat endosperm WEAX ranges from $200-300 \mathrm{kDa}$ with a high polydispersity index between 1,7 and 2 reflecting a range of polymers exhibiting different masses and structures polymolecularity [27].

This polydispersity was demonstrated when a range of polymers with MW varying from $7 \mathrm{kDa}$ to 655 $\mathrm{kDa}$, with $\mathrm{A} / \mathrm{X}$ ratios from 0,4 to 1,2 were isolated from WEAX with an initial MW of $280 \mathrm{kDa}$; however no relationship was observed between the MW and the polymers' structures. In contrast, higher MW of $850 \mathrm{kDa}$ has been reported for AEAX from wheat endosperm [32, 33].

\section{Viscosity}

AXs form highly viscous solutions displaying pseudoplastic behaviour and can form weak gels at low shear. Both WEAX and AEAX are capable of forming highly viscous aqueous solutions, due to their high molecular weight, stiff, semi - flexible random coil conformation, molecular weight distribution and concentration. This is contrary to the general assumptions that it is the $\mathrm{A} / \mathrm{X}$ ratio alone that affects viscosity. Ferulic acid cross linked to AXs also contributes to viscosity, by increasing the molecular weight and changing the conformation of the AXs molecule. A higher viscosity is seen with higher 
concentrations of AXs and MW [20, 23].

Viscosities reported for WEAX in wheat are in the range $200-600 \mathrm{ml} / \mathrm{g}$ with an average value of 400 $\mathrm{ml} / \mathrm{g}$. Although some differences between studies can result from different extraction procedures (and especially in the inactivation of endogenous enzymes), for the same extraction procedure variation is cultivar-related, and may depend on variation in the molecular weight or in the conformation of the polymer [16, 23].

\section{Water solubility}

A main factor affecting solubility of AXs in water is substitution degree (DS), as the presence of high numbers of arabinose molecules prevents intermolecular aggregation of unsubstituted xylose residues. The substitution pattern of arabinose substituents on the xylan backbone also has a definite effect on how the molecules interact with each other and with other cell wall polymers, and thus affects water solubility. Areas of the AXs molecule where there are large amounts of unsubstituted xylose residues allow intermolecular aggregation. Izydorczyk and Biliaderis showed the presence of noncovalent interactions between AXs molecules with low substitution patterns and fragments of $\beta$-glucans and suggested that, in plant cell wall material, poor water solubility of AXs molecules with low $\mathrm{A} / \mathrm{X}$ ratios could be due to these interactions [13, 23].

Water solubility of AXs is therefore linked to the degree of substitution $\mathrm{A} / \mathrm{X}$ ratio, substitution pattern and chain length of the polymer. Insoluble AXs have few arabinose side substituents and long regions of smooth xylan chains which form a flexible twisted threefold ribbon-like structure, becoming insoluble due to intermolecular $\mathrm{H}$ bond linkages [13, 21, 23].

With the introduction of arabinose substituents on the xylan backbone, the ability for this intermolecular linking is reduced, enhancing water solubility, meaning AXs molecules with higher degrees of substitution are expected to be more water soluble. Work Izydorczyk confirmed water solubility to be affected by the degree of substitution. They removed arabinose side chains from AXs polymers with $\alpha$-L-arabinofuranosidase, producing AXs with differing degrees of substitution, and showed that solubility dramatically declined at an $\mathrm{A} / \mathrm{X}$ ratio of 0,43 due to increased aggregation of unsubstituted regions stabilised by hydrogen bonds. A high degree of substitution, however, does not always lead to increased water solubility. Saulnier argue that although endosperm and pericarp WUAX have higher $\mathrm{A} / \mathrm{X}$ ratios than WEAX, which should lead to higher water solubility, instead a large numbers of chain - to - chain cross linking occurs due to 'diferulic bridges', making the WUAX insoluble $[13,23]$.

\section{Water holding capacity}

Both WEAX and WUAX absorb water well. Courtin report WUAX being able to hold $7-10$ times their weight in water, with the water holding capacity of WEAX slightly lower at $4-6$ times their weight. Other workers have shown that when AXs is added to bread dough, the resulting increased resistance to mixing can be compensated by the addition of $2-10$ times their weight in water depending on the solubility and source of the AXs. Studies into the water absorption capacity of
AXs have found an increase in farinograph absorption when AXs are added to flours at different levels [32].

Using farinograph absorption as a measure of water holding capacity is reported as questionable, as it is not clear whether the increase in water absorption is due to the AXs on its own or to the interaction of AXs with other components in the dough. Instead a 'water - binding capacity' figure has been determined and is quoted for wheat bran as being the amount of water retained after centrifugation of the insoluble substrate at $3-7$ $\mathrm{ml} / \mathrm{g}$ dry pellet. A value of $0,4 \mathrm{~g} / \mathrm{g}$, representing the amount of non - freezable water in the sample, was reported irrespective of the origin of $\mathrm{WEAX}$ or $\mathrm{A} / \mathrm{X}$ ratio $[16,21]$.

Water absorption and retention by insoluble AXs are important properties, as they can alter the water distribution within different food components, phenomena particularly useful in bread making.

In general, WEAX form viscous solutions in water whilst WUAX exhibit strong water binding capacity, however conformation and interaction properties can be altered by causing fine structural changes to the polymers which would affect their ability to absorb water and therefore affect their functionality $[15,16]$.

Oxidative cross linking and gel forming capacity

The structure of AXs plays in important part in their ability to form gels. In the presence of free radical generating agents such as chemicals or enzymes, feruloylated AXs undergoes oxidative gelation, increasing in viscosity with the eventual formation of a gel. This is a unique property of AXs and happens due to the creation of covalent cross linkages as a result of dimerization of ferulic acid residues [13].

Strong gels form as a result of high levels of ferulic acid, high MW and a low level of substitution on the xylan backbone, leading to extensive cross linking. The intrinsic viscosity of AXs molecules appears to determine rigidity, rather than ferulic acid content, with stronger gels being obtained with increasing viscosity. High molecular weight AXs form rigid cross - linked hydrogels owning to their greater water holding capacities. Hydrogen bonding and van der Waals forces also form additional weak linkages which increase gel strength. These features establish a positive correlation between gel rigidity and the intrinsic viscosity of AXs molecules $[16,21]$.

\section{Foam stability}

AXs are capable of stabilizing protein films against thermal disruption, thought to be as a result of the increase in viscosity of the interlamellar liquid caused by AXs, and ability to interact with the proteins absorbed in the foam cells, which alters the drainage properties of a foam film. Stabilisation during heating of protein foams with added AXs increases with AXs molecular size, due to the prevention of disruption of gas cells during thermal expansion of $\mathrm{CO}_{2}$.

These functional properties all have the potential to affect the bread making process, to enhance the technological functionality of bread dough, production of food ingredients, including prebiotic substances arabinoxylooligosacchrides (AXOC) [12, 13, 23]. 


\section{REFERENCES}

1. Amreina T. In vitro digestibility and colonic ferment ability of aleurone isolated from wheat bran / T. Amreina, R. Amad, P. Gr.anicherb // Lebensmittel Wissenschaft und Technologie. - 2003. - Vol. 36, Is.1. - P. 451 - 460. DOI: 10.1016/S00236438(03)00036-7

2. Pomeranz Y. Chemical composition of kernel structures // Wheat: Chemistry and technology. St. Paul, MN: American Association of Cereal Chemists. - 1988. - Vol.1. - P. $97-158$.

3. Lupton J. R. Potential protective mechanisms of wheat bran fibre / J. R. Lupton \& N. D. Turner // American Journal of Medicine. - 1999. - Vol. 106, Is. - P. 24 - 27. DOI: 10.1016/S0002-9343(98)00343-X

4. Ha rko nen H. Distribution and some properties of cell wall polysaccharides in rye milling fractions / H. Härko nen, E. Pessa, T. Suortti // Journal of Cereal Science. - 1997. - Vol. 26, Is. - P. 95 - 104. DOI: 10.1006/jcrs. 1996.0106

5. Aguedoa M. Extraction by three processes of arabinoxylans from wheat bran and characterization of the fractions obtained / M. Aguedoa, C. Fougniesb // Carbohydrate Polymers. - 2014. - Vol. 105. - P.317 - 324. DOI: 10.1016/j.carbpol.2014.01.096

6. Lu Z.X. Arabinoxylan fibre improves metabolic control in people with Type II diabetes / Z. X. Lu, K. Z. Walker, J. G. Muir, K. O'Dea // European Journal of Clinical Nutrition. - 2004. - Vol. 58. - P.621 - 628. DOI: 10.1038/sj.ejcn.1601857

7. Falck P. Xylooligosaccharides from hardwood and cereal xylans produced by a thermostable xylanase as carbon sources for Lactobacillus brevis and Bifidobacterium adolescents / P. Falck, S. Precha-Atsawanan, C. Grey, P. Immerzeel, et all. // Journal of Agricultural and Food Chemistry. - 2013. - Vol. 61. - P.733. DOI: 10.1021/jf401249g

8. Geraylou Z. Prebiotic effects of arabinoxylans-oligosaccharides (AXOS) on juvenile Siberian sturgeon (Acipenser baerii) with emphasis on the modulation of the gut microbiota using 454 pyrosequencing / Z. Geraylou, C. Rurangwa, E. Maes, G. E. Spanier, et al. // FEMS Microbiology Ecology. - 2013. - Vol. 86. - P. 357-371. DOI: 10.1111/1574-6941.12169

9. Gibson G. R. Dietary modulation of the human colonic microbiota: Updating the concept of prebiotics / G. R. Gibson, H. M. Probert, J. van Loo, R. A Rastall // Nutrition Research Reviews. - 2004. - Vol. 17. - P. 259-275. DOI: 10.1079/NRR200479

10. Zhurlova O. The current trends and future perspectives of arabinoxylans prebiotics research: a review / O.D. Zhurlova, L.V. Kaprelyants // Grain Products and Mixed Fodder's. - 2017. - Vol.17. - P.4 - 11. DOI: 10.15673/gpmf.v17i4.760

11. Rao R. S. P. Water soluble feruloyl arabinoxylans from rice and rage: Changes upon malting and their consequence on antioxidant activ-ity / R. S. P. Rao, G. Muralikrishna // Photochemistry. - 2006. - Vol. $-P .67-91$. DOI: 10.1016/j.phytochem.2005.09.036

12. Kaprelyants L.V. Technology of wheat and rye bran biotransformation into functional ingredients /L.V. Kaprelyants, O. D. Zhurlova // International Food Research Journal. - 2017. - Vol.24. - P.1975 - 1979. ISSN: 1985-4668 (Scopus)

13. Izydorczyk M. Physical properties of water-soluble pentosanes from different wheat varieties / M. Izydorczyk, C. Biliaderis, W Bushuk // Journal Cereal Chemistry. - 1995. - Vol. 68, Is.. - P.145 - 150.

14. Saeed F. Arabinoxylans and arabinogalactans: a comprehensive treatise / F. Saeed, I. Pasha, F. Anjum, and M. Sultan // Critical Reviews in Food Science and Nutrition. - 2011. - Vol. 51, Is.3. - P. 467 - 476. DOI: 10.1080/10408391003681418

15. Maes C. Structural characterization of water-extractable and water-unextractable arabinoxylans in wheat bran / C. Maes, J. Delcour //Journal of Cereal Science. -2002. - Vol. 35, Is.4. - P. 315 - 326. DOI: 10.1006/jcrs.2001.0439

16. Saulnier L. Wheat arabinoxylans: Exploiting variation in amount and composition to develop enhanced varieties / L. Saulnier, S. Pierre-Etienne, B. Gerard //Journal of Cereal Science. - 2007. - Vol. 46-P. 261-281. DOI: 10.1016/j.jcs.2007.06.014

17. Escarnot E. Extraction and characterization of water-extractable and water-unextractable arabinoxylans from spelt bran: Study of the hydrolysis conditions for monosaccharides analysis / E. Escarnot, M. Aguedo, R. Agneessens, B. Wathelet // Journal of Cereal Science. - 2009. - Vol. 65 - P. 51 - 95. DOI: 10.1016/j.jcs.2010.09.002

18. Mustafa M. Evaluating the feasibility of commercial arabinoxylan production in the context of a wheat biorefinery principally producing ethanol / M. Mustafa, N. Misailidis, F. Mateos-Salvador, Du C. // Chemical Engineering Research and Design. 2007. - Vol. 87. - P. 1239-1250. DOI: 10.1016/j.cherd.2008.12.027

19. Delcour J. Principles of Cereal Science and Technology J. Delcour, R. Hoseney // AACC International, Inc., Minnesota, USA. 2010. - P. 541 - 560. DOI: 10.1002/star.19870390416

20. Maes C. Alkaline hydrogen peroxide extraction of wheat bran non-starch polysaccharides / C. Maes, J. Delcour // Journal of Cereal Science. - 2001. - Vol.34. - P. 29 - 35. DOI: 10.1006/jcrs.2001.0377

21. Saulnier L. Plant cell wall polysaccharides in storage organs: Xylans (food applications) / L. Saulnier, F. Guillon, P. Sado and X. Rouau // Plant Polysaccharides. - 2007. - Vol.1. DOI: 10.1016/B978-0-12-409547-2.01493-1

22. Van den Bulck K. Amino acid sequence of wheat flour arabinogalactan - peptide, identical to part of grain softness protein GSP1, leads to improved structural model / K. Van den Bulck, A. Loosveld, C. Courtin, P. Proost, J. Van Damme, J. Robben, A. Mort // Cereal Chemistry. - 2002. - Vol. 79, Is.3. P. 329-331. DOI: 10.1094/CCHEM.2002.79.3.329

23. Izydorczyk M. Arabinoxylans: Technologically and Nutritionally Functional Plant Polysaccharides / M. Izydorczyk, C. Biliaderis // Taylor and Francis Group. LLC. Oxford, UK. - 2007.

24. Saulnier L. Variability in grain extract viscosity and water- soluble arabinoxylan content in wheat / L. Saulnier, N. Peneau and J. Thibault // Journal of Cereal Science. - 1995. - Vol. 22. - P. 259-264. DOI: 10.1006/jcrs. 1995.0062

25. Zhou S. Comparison of the immunological activities of arabinoxylans from wheat bran with alkali and xylanase aided extraction / S. Zhou, X. Liu // Carbohydrate Polymers. - 2010. - Vol.81. - P.84 - 89. DOI: 10.1016/j.carbpol.2010.03.040

26. Antoine C. Individual contribution of grain outer layers and their cell wall structure to the mechanical properties of wheat bran $/$ C. Antoine, S. Peyron, F. Mabille, C. Lapierre, B. Bouchet, J. Abecassis and X. Rouau // Journal of Agricultural and Food Chemistry. - 2003. - Vol. 55, Is.1. - P. 2026-2033. DOI: 10.1021/jf0261598

27. Gebruers K. Variation in the content of dietary fiber and components thereof in wheats in the health grain diversity screen / K. Gebruers, E. Dornez, D. Boros, A. Frás, W. Dynkowska, Z. Bedo, M. Rakszegi, J. Delcour and C. Courtin // Journal of Agricultural and Food Chemistry. - 2008. - Vol.56. - P. 9740 - 9749. DOI: 10.1021/jf800975w

28. Misailidis N. Evaluating the feasibility of commercial arabinoxylan production in the context of a wheat biorefinery principally producing ethanol. Part 2. Process simulation and economic analysis / N. Misailidis, G. Campbell, Du, J. Sadhukhan, M. Mustafa, F. Mateos-Salvador and R. Weightman // Chemical Engineering Research and Design.- 2009. - Vol. 87. - P. $1239-1250$. DOI: $10.1016 /$ j.cherd.2008.12.028

29. Hollmann J. Pilot - scale isolation of glucuronoarabinoxylans from wheat bran / J. Hollmann and M. Lindhauer // Carbohydrate Polymers. - 2005. - Vol. 59. - P. 225 - 230. DOI: 10.1016/j.carbpol.2004.09.015 
30. Weightman R. Towards defining optimal feedstocks for a wheat biorefinery: Co-production of arabinoxylans with bioethanol / R. Weightman, H.R Davis-Knight, N. Misailidis, A. Villanueva and G. Campbell // Aspects of Applied Biology. Biomass and Energy Crops III. - 2008. - P. $153-160$.

31. Antoine C. Individual contribution of grain outer layers and their cell wall structure to the mechanical properties of wheat bran $/$ C. Antoine, S. Peyron, F. Mabille, C. Lapierre, B. Bouchet, J. Abecassis and X. Rouau // Journal of Agricultural and Food Chemistry. - 2003. - Vol. 55, Is.1. - P. 2026-2033. DOI: 10.1021/jf0261598

32. Hashimoto S. Cereal pentosans: their estimation and significance. Pentosans in wheat and milled wheat products / S. Hashimoto, I. Shogren and Y. Pomeranz // Cereal Chemistry. - 1987. - Vol. 64. - P. 30.

33. Cyran M. Heterogeneity in the fine structure of alkali-extractable arabinoxylans isolated from two rye flours with high and low bread making quality and their coexistence with other cell wall components / M. Cyran, C. Courtin and J. Delcour // Journal of Agricultural and Food Chemistry. - 2004. - Vol. 52, Is.5. - P.2671 - 2680. DOI: 10.1021/jf030550r

34. Adam A. The bioavailability of ferulic acid is governed primarily by the food matrix rather than its metabolism in intestine and liver in rats / A. Adam, V. Crespy, M. A. Levrat-Verny, F. Leenhardt, M. Leuillet, C. Demigne and C. Remesy // Nutrition Research Reviews. - 2002. - Vol.132, Is.7. - P. 1962 - 1968. DOI: 10.1093/jn/132.7.1962

35. Harder H. Rye bran bread intake elevates urinary excretion of ferulic acid in humans, but does not affect the susceptibility of LDL to oxidation ex vivo / H. Harder, I. Tetens, M. Let and A. Meyer // Eur. J. Nutrition Research Reviews. - 2004. - Vol.43, Is.2. - P. 230-236. DOI: 10.1007/s00394-004-0463-5

36. Mateo N. Bioavailability of ferulic acid is determined by its bioaccessibility / N. Mateo Anson, R. Van den Berg, R. Havenaar, and G. R. M. M. Haenen // Journal of Cereal Science. - 2009. - Vol.49. - P. 296 - 300. DOI: 10.1111/j.1365-2125.2012.04425.x

37. Mathew S. Ferulic acid: an antioxidant found naturally in plant cell walls and feruloyl esterases involved in its release and their applications / S. Mathew and T. E. Abraham //Crit. Rev. Biotechnology. -2004. Vol.24. - P. 59. DOI: 10.1080/07388550490491467

38. Dornez E. Grain-associated xylanases: occurrence, variability, and implications for cereal processing / E. Dornez, K. Gebruers, J. A. Delcour and C. M. Courtin // Journal Food Science Technol. - 2009.- Vol.20. - P. 495 - 510. DOI: 10.1016/j.tifs.2009.05.004

39. Wang J. Inhibitory effect of wheat bran feruloyl oligosaccharides on oxidative DNA damage in human lymphocytes /J. Wang, B. Sun, Y. Cao, H. Song and Y. Tian // Food Chemistry. - 2008. - Vol.109. - P. 129-136. DOI: 10.1016/j.foodchem.2007.12.031

40. Bhanja T. Enrichment of phenolic and free radical scavenging property of wheat koji prepared with two filamentous fungi $/ T$. Bhanja, A. Kumari // Bioresour Technol. - 2009. - Vol.100. - P.2861 - 2866. DOI: 10.1016/j.biortech.2008.12.055

41. Moore J. Effects of solid-state enzymatic treatments on the antioxidant properties of wheat bran / J. Moore, Z. Cheng, L. Su and L. Yu, // Journal Argic Food Chem. - 2006.- Vol.54. - P. 9032 - 9045. DOI: 10.1021/jf0616715

42. Anson N. M. Bioprocessing of wheat bran improves in vitro bioaccessibility and colonic metabolism of phenolic compounds / N. M. Anson, E. Selinheimo, R. Havenaar, A.M. Aura, I. Mattila, P. Lehtinen, A. Bast, K. Poutanen and G. R. M. M. Haenen // Journal Agric Food Chem. - 2009.- Vol.57. - P. 6148 - 6155. DOI: 10.1021/jf900492h

43. Anson N. M. Bioprocessing of wheat bran in whole wheat bread increases the bioavailability of phenolic acids in men and exerts antiinflammatory effects ex vivo / N. M. Anson, A. M. Aura, E. Selinheimo, I. Mattila, K. Poutanen, R. Van den Berg, R. Havenaar, A. Bast //J Nutrition Research Reviews. - 2011.-Vol.141. - P. 137 - 143. DOI: 10.3945/jn.110.127720

44. Yoshida-Shimokawa T. Enzymic feruloylation of arabinoxylan-trisaccharide by feruloyl-CoA: arabinoxylan-trisaccharide Ohydroxycinnamoyl transferase from Oryza sativa / T. Yoshida-Shimokawa, S. Yoshida, K. Kakegawa and T.Ishii // Planta 212.2001. - P.470-474. DOI: 10.1007/s004250000490

45. Ramseyer D. Water-Unextractable and Water-Extractable Arabinoxylans in Wheat Flour Mill Streams / D. Ramseyer A. Bettge and C. Morris // Cereal Chemistry. - 2011. - Vol. 88, P. 209-216. DOI: 10.1094/CCHEM-10-10-0148

\section{УДК [577.114.4:633.11]:57.0.13}

${ }^{1}$ Л. В. Капрельянц, д-р техн. наук., професор ${ }^{1}$ Л. Г. Пожіткова, канд. техн. наук, асистент ${ }^{1}$ Т. О. Велічко, канд. техн. наук, доцент ${ }^{2}$ О. А. Білик, канд. техн. наук, доцент ${ }^{l}$ Одеська національна академія харчових технологій, м. Одеса, Украӥна ${ }^{2}$ Національній університет харчових технологій, м. Київ, Україна

\section{АРАБІНОКСИЛАНИ ПШЕНИЦІ СТРУКТУРА, ВИЛУЧЕННЯ, ВЛАСТИВОСТІ}

\section{Анотація}

Арабіноксилани (АК) - некрохмальні полісахариди в склад яких входить арабіноза та кислоза, молекулярна маса яких коливається від 50 до $850 \mathrm{kDa}$ в залежності від методу їх вилучення. Основна частина АК зернових знаходиться в структурній матриці клітинних стінок зернових культур, а також присутні у великих кількостях в пшеничних висівках, щчо становить до 15 - 20 \% від їх хімічного складу. Фізико-хімічні властивості АК визначають їх функиіональність, яка може бути корисною особливо для продуктів на основі зернових, таких як хліб та хлібобулочні вироби які містять глютен. При додаванні АК стабілізується та зміцнюється матриця глютену, за рахунок чого підвищується якість хліба та його товарні властивості.

Потенційним джерелом АК - пшеничні висівки які є побічним продуктом борошномельного виробництва, накопичується в достатній кількості при подрібненні зерна та сортуванні його часток за розміром $і$ масою, крім того комериійно доступні у великій кількості. В залежності від розчинності як водорозчинні та нерозчинні АК отримують різними методами: ферментативною обробкою пшеничних висівок або методом екстракції. Вилучення 
АК методом екстракції проводять, щзоб підвищити поживну цінність пшеничних висівок за рахунок вмісту харчових волокон і таким чином отримати високоцінний продукт для використання в якості функиіонального інгредієнта в хлібопекарській промисловості та в інших галузях. Екстракція включає низку можливостей отримання АК з різними фізико - хімічними властивостями, шчо дає можливість їх широкого використання як функціонального інгредієнта в харчові системи. Фізико - хімічні властивості АК включають: в'язкість, розчинність у воді, водозв'язувальну здатність, окисне поперечне зшивання і утворення гелю і стійких пін, взаємодію АК з ланиюгами полімерів та інших речовин.

В даний час комериійні поставки АК не доступні в достатній кількості для проведення випробувань їх функиіональності. Тому метою огляду літератури є вивчення сучасних методів вилучення АК з пшеничних висівок включаючи ензиматичні підходи, аналіз їх структури, та визначення фізико - хімічних властивостей отриманих АК а також можливе подальше їх використання в харчовій промисловості.

Ключові слова: арабіноксилани пшеничні, структура, класифікація, методи вилучення, фізико-хімічні властивості, молекулярна вага, в'язкість, водорозчинність.

\section{ЛITЕР АТУР A}

1. Amreina T. In vitro digestibility and colonic ferment ability of aleurone isolated from wheat bran / T. Amreina, R. Amad, $P$. Gr.anicherb // Lebensmittel Wissenschaft und Technologie. - 2003. - Vol. 36, Is.1. - P. 451 - 460. DOI: 10.1016/S00236438(03)00036-7

2. Pomeranz Y. Chemical composition of kernel structures // Wheat: Chemistry and technology. St. Paul, MN: American Association of Cereal Chemists. - 1988. - Vol.1. - P. $97-158$.

3. Lupton J. R. Potential protective mechanisms of wheat bran fibre / J. R. Lupton \& N. D. Turner // American Journal of Medicine. - 1999. - Vol. 106, Is. - P. 24 - 27. DOI: 10.1016/S0002-9343(98)00343-X

4. Ha rkönen H. Distribution and some properties of cell wall polysaccharides in rye milling fractions / H. Ha rko "nen, E. Pessa, T. Suortti // Journal of Cereal Science. - 1997. - Vol. 26, Is. - P. 95 - 104. DOI: 10.1006/jcrs. 1996.0106

5. Aguedoa M. Extraction by three processes of arabinoxylans from wheat bran and characterization of the fractions obtained / M. Aguedoa, C. Fougniesb // Carbohydrate Polymers. - 2014. - Vol. 105. - P.317 - 324. DOI: 10.1016/j.carbpol.2014.01.096

6. Lu Z.X. Arabinoxylan fibre improves metabolic control in people with Type II diabetes / Z. X. Lu, K. Z. Walker, J. G. Muir, K. O'Dea // European Journal of Clinical Nutrition. - 2004. - Vol. 58. - P.621 - 628. DOI: 10.1038/sj.ejcn.1601857

7. Falck P. Xylooligosaccharides from hardwood and cereal xylans produced by a thermostable xylanase as carbon sources for Lactobacillus brevis and Bifidobacterium adolescents / P. Falck, S. Precha-Atsawanan, C. Grey, P. Immerzeel, et all. // Journal of Agricultural and Food Chemistry. - 2013. - Vol. 61. - P.733. DOI: 10.1021/jf401249g

8. Geraylou Z. Prebiotic effects of arabinoxylans-oligosaccharides (AXOS) on juvenile Siberian sturgeon (Acipenser baerii) with emphasis on the modulation of the gut microbiota using 454 pyrosequencing / Z. Geraylou, C. Rurangwa, E. Maes, G. E. Spanier, et al. // FEMS Microbiology Ecology. - 2013. - Vol. 86. - P. 357-371. DOI: 10.1111/1574-6941.12169

9. Gibson G. R. Dietary modulation of the human colonic microbiota: Updating the concept of prebiotics / G. R. Gibson, H. M. Probert, J. van Loo, R. A Rastall // Nutrition Research Reviews. - 2004. - Vol. 17. - P. 259 - 275. DOI: 10.1079/NRR200479

10. Zhurlova O. The current trends and future perspectives of arabinoxylans prebiotics research: a review / O.D. Zhurlova, L.V. Kaprelyants // Grain Products and Mixed Fodder's. - 2017. - Vol.17. - P.4 - 11. DOI: 10.15673/gpmf.v17i4.760

11. Rao R. S. P. Water soluble feruloyl arabinoxylans from rice and rage: Changes upon malting and their consequence on antioxidant activ-ity / R. S. P. Rao, G. Muralikrishna // Photochemistry. - 2006. - Vol. $-P \quad 67 \quad-91$. DOI: $10.1016 /$ j.phytochem.2005.09.036

12. Kaprelyants L.V. Technology of wheat and rye bran biotransformation into functional ingredients /L.V. Kaprelyants, O. D. Zhurlova // International Food Research Journal. - 2017. - Vol.24. - P.1975 - 1979. ISSN: 1985-4668 (Scopus)

13. Izydorczyk M. Physical properties of water-soluble pentosanes from different wheat varieties / M. Izydorczyk, C. Biliaderis, W Bushuk // Journal Cereal Chemistry. - 1995. - Vol. 68, Is.. - P.145 - 150.

14. Saeed F. Arabinoxylans and arabinogalactans: a comprehensive treatise / F. Saeed, I. Pasha, F. Anjum, and M. Sultan // Critical Reviews in Food Science and Nutrition. - 2011. - Vol. 51, Is.3. - P. $467-476$. DOI: 10.1080/10408391003681418

15. Maes C. Structural characterization of water-extractable and water-unextractable arabinoxylans in wheat bran / C. Maes, J. Delcour //Journal of Cereal Science. -2002. - Vol. 35, Is.4. - P. 315 -326. DOI: 10.1006/jcrs.2001.0439

16. Saulnier L. Wheat arabinoxylans: Exploiting variation in amount and composition to develop enhanced varieties / L. Saulnier, S. Pierre-Etienne, B. Gerard //Journal of Cereal Science. - 2007. - Vol. 46-P. 261 - 281. DOI: 10.1016/j.jcs.2007.06.014

17. Escarnot E. Extraction and characterization of water-extractable and water-unextractable arabinoxylans from spelt bran: Study of the hydrolysis conditions for monosaccharides analysis / E. Escarnot, M. Aguedo, R. Agneessens, B. Wathelet // Journal of Cereal Science. - 2009. - Vol. 65 - P. 51 - 95. DOI: 10.1016/j.jcs. 2010.09 .002

18. Mustafa M. Evaluating the feasibility of commercial arabinoxylan production in the context of a wheat biorefinery principally producing ethanol / M. Mustafa, N. Misailidis, F. Mateos-Salvador, Du C. // Chemical Engineering Research and Design. 2007. - Vol. 87. - P. 1239-1250. DOI: 10.1016/j.cherd.2008.12.027

19. Delcour J. Principles of Cereal Science and Technology /J. Delcour, R. Hoseney // AACC International, Inc., Minnesota, USA. 2010. - P. 541 - 560. DOI: 10.1002/star.19870390416

20. Maes C. Alkaline hydrogen peroxide extraction of wheat bran non-starch polysaccharides / C. Maes, J. Delcour // Journal of Cereal Science. - 2001. - Vol.34. - P. 29 - 35. DOI: 10.1006/jcrs.2001.0377

21. Saulnier L. Plant cell wall polysaccharides in storage organs: Xylans (food applications) / L. Saulnier, F. Guillon, P. Sado and X. Rouau // Plant Polysaccharides. - 2007. - Vol.1. DOI: 10.1016/B978-0-12-409547-2.01493-1

22. Van den Bulck K. Amino acid sequence of wheat flour arabinogalactan - peptide, identical to part of grain softness protein GSP1, leads to improved structural model / K. Van den Bulck, A. Loosveld, C. Courtin, P. Proost, J. Van Damme, J. Robben, A. Mort // Cereal Chemistry. - 2002. - Vol. 79, Is.3. P. 329 - 331. DOI: 10.1094/CCHEM.2002.79.3.329

23. Izydorczyk M. Arabinoxylans: Technologically and Nutritionally Functional Plant Polysaccharides / M. Izydorczyk, C. Biliaderis // Taylor and Francis Group. LLC. Oxford, UK. - 2007. 
24. Saulnier L. Variability in grain extract viscosity and water-soluble arabinoxylan content in wheat / L. Saulnier, N. Peneau and J. Thibault // Journal of Cereal Science. - 1995. - Vol. 22. - P. 259-264. DOI: 10.1006/jcrs. 1995.0062

25. Zhou S. Comparison of the immunological activities of arabinoxylans from wheat bran with alkali and xylanase aided extraction / S. Zhou, X. Liu // Carbohydrate Polymers. - 2010. - Vol.81. - P.84 - 89. DOI: 10.1016/j.carbpol.2010.03.040

26. Antoine C. Individual contribution of grain outer layers and their cell wall structure to the mechanical properties of wheat bran $/$ C. Antoine, S. Peyron, F. Mabille, C. Lapierre, B. Bouchet, J. Abecassis and X. Rouau // Journal of Agricultural and Food Chemistry. - 2003. - Vol. 55, Is.1. - P. 2026-2033. DOI: 10.1021/jf0261598

27. Gebruers K. Variation in the content of dietary fiber and components thereof in wheats in the health grain diversity screen / K. Gebruers, E. Dornez, D. Boros, A. Frás, W. Dynkowska, Z. Bedo, M. Rakszegi, J. Delcour and C. Courtin // Journal of Agricultural and Food Chemistry. - 2008. - Vol.56. - P. 9740 - 9749. DOI: 10.1021/jf800975w

28. Misailidis N. Evaluating the feasibility of commercial arabinoxylan production in the context of a wheat biorefinery principally producing ethanol. Part 2. Process simulation and economic analysis / N. Misailidis, G. Campbell, Du, J. Sadhukhan, M. Mustafa, F. Mateos-Salvador and R. Weightman // Chemical Engineering Research and Design.- 2009. - Vol. 87. - P. 1239 - 1250. DOI: $10.1016 /$ j.cherd.2008.12.028

29. Hollmann J. Pilot - scale isolation of glucuronoarabinoxylans from wheat bran / J. Hollmann and M. Lindhauer // Carbohydrate Polymers. - 2005. - Vol. 59. - P. 225 - 230. DOI: 10.1016/j.carbpol.2004.09.015

30. Weightman R. Towards defining optimal feedstocks for a wheat biorefinery: Co-production of arabinoxylans with bioethanol / $R$. Weightman, H.R Davis-Knight, N. Misailidis, A. Villanueva and G. Campbell // Aspects of Applied Biology. Biomass and Energy Crops III. - 2008. - P. $153-160$.

31. Antoine C. Individual contribution of grain outer layers and their cell wall structure to the mechanical properties of wheat bran $/$ C. Antoine, S. Peyron, F. Mabille, C. Lapierre, B. Bouchet, J. Abecassis and X. Rouau // Journal of Agricultural and Food Chemistry. - 2003. - Vol. 55, Is. 1. - P. 2026-2033. DOI: 10.1021/jf0261598

32. Hashimoto S. Cereal pentosans: their estimation and significance. Pentosans in wheat and milled wheat products / S. Hashimoto, I. Shogren and Y. Pomeranz // Cereal Chemistry. - 1987. - Vol. 64. - P. 30.

33. Cyran M. Heterogeneity in the fine structure of alkali-extractable arabinoxylans isolated from two rye flours with high and low bread making quality and their coexistence with other cell wall components / M. Cyran, C. Courtin and J. Delcour // Journal of Agricultural and Food Chemistry. - 2004. - Vol. 52, Is.5. - P.2671 - 2680. DOI: 10.1021/jf030550r

34. Adam A. The bioavailability of ferulic acid is governed primarily by the food matrix rather than its metabolism in intestine and liver in rats / A. Adam, V. Crespy, M. A. Levrat-Verny, F. Leenhardt, M. Leuillet, C. Demigne and C. Remesy // Nutrition Research Reviews. - 2002. - Vol.132, Is.7. - P. 1962 - 1968. DOI: 10.1093/jn/132.7.1962

35. Harder H. Rye bran bread intake elevates urinary excretion of ferulic acid in humans, but does not affect the susceptibility of LDL to oxidation ex vivo / H. Harder, I. Tetens, M. Let and A. Meyer // Eur. J. Nutrition Research Reviews. - 2004. - Vol.43, Is.2. - P. 230-236. DOI: 10.1007/s00394-004-0463-5

36. Mateo N. Bioavailability of ferulic acid is determined by its bioaccessibility / N. Mateo Anson, R. Van den Berg, R. Havenaar, and G. R. M. M. Haenen // Journal of Cereal Science. - 2009. - Vol.49. - P. 296 - 300. DOI: 10.1111/j.1365-2125.2012.04425.x

37. Mathew S. Ferulic acid: an antioxidant found naturally in plant cell walls and feruloyl esterases involved in its release and their applications / S. Mathew and T. E. Abraham //Crit. Rev. Biotechnology. -2004. Vol.24. - P. 59. DOI: 10.1080/07388550490491467

38. Dornez E. Grain-associated xylanases: occurrence, variability, and implications for cereal processing / E. Dornez, K. Gebruers, J. A. Delcour and C. M. Courtin // Journal Food Science Technol. - 2009.- Vol.20. - P. 495 - 510. DOI: 10.1016/j.tifs.2009.05.004

39. Wang J. Inhibitory effect of wheat bran feruloyl oligosaccharides on oxidative DNA damage in human lymphocytes / J. Wang, B. Sun, Y. Cao, H. Song and Y. Tian // Food Chemistry. - 2008. - Vol.109. - P. 129-136. DOI: 10.1016/j.foodchem.2007.12.031

40. Bhanja T. Enrichment of phenolic and free radical scavenging property of wheat koji prepared with two filamentous fungi $/ T$. Bhanja, A. Kumari // Bioresour Technol. - 2009. - Vol.100. - P.2861 - 2866. DOI: 10.1016/j.biortech.2008.12.055

41. Moore J. Effects of solid-state enzymatic treatments on the antioxidant properties of wheat bran /J. Moore, Z. Cheng, L. Su and L. Yu, // Journal Argic Food Chem. - 2006.- Vol.54. - P. 9032 - 9045. DOI: 10.1021/jf0616715

42. Anson N. M. Bioprocessing of wheat bran improves in vitro bioaccessibility and colonic metabolism of phenolic compounds / N. M. Anson, E. Selinheimo, R. Havenaar, A.M. Aura, I. Mattila, P. Lehtinen, A. Bast, K. Poutanen and G. R. M. M. Haenen // Journal Agric Food Chem. - 2009.- Vol.57. - P. 6148 - 6155. DOI: 10.1021/jf900492h

43. Anson N. M. Bioprocessing of wheat bran in whole wheat bread increases the bioavailability of phenolic acids in men and exerts antiinflammatory effects ex vivo / N. M. Anson, A. M. Aura, E. Selinheimo, I. Mattila, K. Poutanen, R. Van den Berg, R. Havenaar, A. Bast //J Nutrition Research Reviews. - 2011.-Vol.141. - P. 137-143. DOI: 10.3945/jn.110.127720

44. Yoshida-Shimokawa T. Enzymic feruloylation of arabinoxylan-trisaccharide by feruloyl-CoA: arabinoxylan-trisaccharide Ohydroxycinnamoyl transferase from Oryza sativa / T. Yoshida-Shimokawa, S. Yoshida, K. Kakegawa and T.Ishii // Planta 212. 2001. - P.470- 474. DOI: $10.1007 /$ s004250000490

45. Ramseyer D. Water-Unextractable and Water-Extractable Arabinoxylans in Wheat Flour Mill Streams / D. Ramseyer A. Bettge and C. Morris // Cereal Chemistry. - 2011. - Vol. 88, P. 209-216. DOI: 10.1094/CCHEM-10-10-0148

Надійшла 11.03.2019 р. Рецензія 28.03.2019. До друку 07.06.2019. Адреса для переписки: вул. Канатна, 112, м. Одеса, 65039 pozhitkova@ukr.net

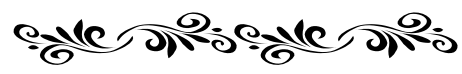

